\title{
Author reply to comment by Brandenburg et al. on: Large differences between test strategies for the detection of anti-Borrelia antibodies are revealed by comparing eight ELISAs and five immunoblots
}

\author{
C. W. Ang
}

Received: 6 May 2011 / Accepted: 15 May 2011 / Published online: 31 May 2011

(C) The Author(s) 2011. This article is published with open access at Springerlink.com

\section{Dear Editor,}

We thank our colleagues for their valuable contribution and comments on our recent article [1]. First, we completely agree that for a thorough judgment of any assay samples from clinically well-defined patients are necessary. Brandenburg et al. correctly state that with the results from the present study, it cannot be concluded which test is the best and it is difficult to discriminate between increased sensitivity and decreased specificity (both leading to an increased number of positive tests). However, this study did not aim to describe a sensitivity for any assay for certain patient groups, nor to define the "best test", but to demonstrate that the results of antibody testing for Borrelia are highly influenced by the choice of assay. The harsh truth is that even in a country as The Netherlands, with more than ten assays and six immunoblots commercially available, many potentially discrepant results are generated every day.

The patients with skin manifestations were predominantly erythema migrans patients, and the neurological patients included only seven patients with symptoms of short duration. We did not observe more discrepant results in the patients with documented symptoms of short duration. The six ELISA positive, blot negative patients were

\section{W. Ang $(\triangle)$}

Department of Medical Microbiology and Infection Control,

VU University Medical Center,

P.O. Box 7057, 1007 MB Amsterdam, The Netherlands

e-mail: w.ang@vumc.nl predominantly neurological patients. In half of the patients there was a longer disease duration, making the possibility of an early manifestation of neuroborreliosis less likely. In only one of these patients, a concordant result in more than one immunoblot was present (IgG antibody reactivity in a patient with chronic pain throughout the body). From our data it is impossible to conclude that immunoblots are more sensitive or less specific, and more extensive studies using appropriate samples from patients with possible cross reacting or aspecifically reacting samples are needed to solve this issue.

For interpretation of Borrelia serology, clinical information is indispensable. Part of the discrepancies between the tests will be resolved when taking into account the clinical picture (e.g. isolated low IgM seropositivity in a patient with chronic complaints is suspicious for falsepositivity, even with a positive immunoblot). Recognition of a Borrelia infection in a "typical" case of Lyme disease (erythema migrans, monoarthritis of the knee with a history of tick bite, etc.) will not pose a problem in many cases and multiple studies demonstrate high sensitivity for serological tests in these selected patient groups. However, for clinical syndromes with a low a priori chance of Borrelia infection (facial nerve paralysis, sudden deafness, chronic joint pain, etc.) there is no clinical "gold standard" and we have to rely on serological tests.

Our samples include six patients with "definite Lyme disease" (5 erythema migrans, 1 neuroborreliosis), 37 without Lyme disease (patients with an alternative diagnosis and the control patients) and 46 samples from patients 
Table 1 Elisa $\mathrm{x}$ blot combinations per diagnosis group in 31 samples

\begin{tabular}{llll}
\hline $\begin{array}{l}\text { Number of positive ELISA x blot } \\
\text { combinations }\end{array}$ & $\begin{array}{l}\text { Definite } \\
\text { Lyme }\end{array}$ & $\begin{array}{l}\text { Possible } \\
\text { Lyme }\end{array}$ & $\begin{array}{l}\text { Definitely } \\
\text { not Lyme }\end{array}$ \\
\hline 0 & 0 & 12 & 1 \\
$1-8$ & 0 & 4 & 1 \\
$9-23$ & 0 & 1 & 1 \\
$24-39$ & 2 & 2 & 0 \\
40 & 2 & 5 & 0 \\
Total number of patients & 4 & 24 & 3 \\
\hline
\end{tabular}

with complaints that were compatible with Lyme disease but not typical. For this group of patients Borrelia antibody testing was performed in order to make a diagnosis ("possible Lyme disease"). This last group forms the most interesting group and the results in this group probably illustrate our message most clearly. In 31 samples that were tested in all eight ELISA's and all five blots there were 24 samples from patients with "possible Lyme" (Table 1). From these 24 patients, 12 had a positive ELISA x blot combination and five of these 12 were positive in all 40 combinations. Therefore there were discrepancies in $7 / 24=$ $29 \%$ of these patients. However, the patients in this study were partly selected based on reactivity in one screening test (VIDAS) and the observed percentage discrepancies may be overestimated.

To circumvent the problem of biased agreement due to the inclusion of "indeterminate" results, we scored all "indeterminate", "grey zone" and "borderline" results as negative. Separate agreement analysis of $\operatorname{IgG}$ and $\operatorname{IgM}$ did not alter our conclusions. Kappa values for $\operatorname{IgG}$ ranged from 0.48 to 0.94 , while for IgM there was generally less agreement with kappa's ranging from 0.32 to 0.68 (Table 2).

In conclusion, we think that our study certainly has limitations but our data clearly demonstrate that the results for Borrelia antibody testing is highly influenced by the laboratory method. The discrepancies in test

Table $2 \operatorname{IgM}$ and $\operatorname{IgG}$ analyses

\begin{tabular}{|c|c|c|c|c|c|c|c|c|c|c|}
\hline \multicolumn{11}{|l|}{ IgM } \\
\hline ELISA manufacturer & \multicolumn{2}{|c|}{ Antigen used for ELISA } & Moran & \multicolumn{2}{|c|}{ Virion/ Serion } & \multicolumn{2}{|c|}{ Enzygnost } & Euroimmun & Virotech & Mediphos \\
\hline Moran & \multicolumn{2}{|l|}{ Whole cell } & - & \multicolumn{2}{|l|}{-} & \multicolumn{2}{|l|}{-} & - & - & - \\
\hline Virion/Serion & \multicolumn{2}{|c|}{ Whole cell + VlsE } & 0.39 & \multicolumn{2}{|l|}{-} & \multicolumn{2}{|l|}{-} & - & - & - \\
\hline Enzygnost & \multicolumn{2}{|c|}{ Whole cell + VlsE } & 0.32 & \multicolumn{2}{|l|}{0.72} & \multicolumn{2}{|l|}{-} & - & - & - \\
\hline Euroimmun & \multicolumn{2}{|c|}{ Whole cell + VlsE } & 0.59 & \multicolumn{2}{|l|}{0.52} & \multicolumn{2}{|c|}{0.43} & - & - & - \\
\hline Virotech & \multicolumn{2}{|c|}{ Whole cell + VlsE } & 0.39 & \multicolumn{2}{|l|}{0.68} & \multicolumn{2}{|c|}{0.53} & 0.36 & - & - \\
\hline Mediphos & \multicolumn{2}{|c|}{ Recombinant } & 0.59 & \multicolumn{2}{|l|}{0.44} & \multicolumn{2}{|c|}{0.34} & 0.68 & 0.44 & - \\
\hline \multicolumn{11}{|l|}{$\operatorname{IgG}$} \\
\hline $\begin{array}{l}\text { ELISA } \\
\text { manufacturer }\end{array}$ & $\begin{array}{l}\text { Antigen used for } \\
\text { ELISA }\end{array}$ & Moran & VIDAS & $\begin{array}{l}\text { Virion/ } \\
\text { Serion }\end{array}$ & Enzy & & Euroimmun & Virotech & Immunetics & Mediphos \\
\hline Moran & Whole cell & - & - & - & - & & - & - & - & - \\
\hline VIDAS & Whole cell & 0.52 & - & - & - & & - & - & - & - \\
\hline Virion/Serion & Whole cell + VlsE & 0.74 & 0.48 & - & - & & - & - & - & - \\
\hline Enzygnost & Whole cell + VlsE & 0.85 & 0.59 & 0.74 & - & & - & - & - & - \\
\hline Euroimmun & Whole cell + VlsE & 0.73 & 0.46 & 0.64 & 0.76 & & - & - & - & - \\
\hline Virotech & Whole cell + VlsE & 0.51 & 0.56 & 0.49 & 0.48 & & 0.6 & - & - & - \\
\hline Immunetics & Recombinant & 0.79 & 0.6 & 0.71 & 0.94 & & 0.71 & 0.49 & - & - \\
\hline Mediphos & Recombinant & 0.82 & 0.57 & 0.79 & 0.91 & & 0.73 & 0.5 & 0.85 & - \\
\hline
\end{tabular}


results are partly resolved by taking into account clinical data and disease duration. We applaud any initiative aimed at increasing the availability of clinical data for laboratories. There will always remain a substantial group of patients in which the decision whether symptoms are attributable to a Borrelia infection crucially depends on the results of serological testing. Our study also illustrates that in this group the choice of assay partly determines the result, and we hope that future harmonization and standardization will minimize the group of patients with discrepant results.
Open Access This article is distributed under the terms of the Creative Commons Attribution Noncommercial License which permits any noncommercial use, distribution, and reproduction in any medium, provided the original author(s) and source are credited.

\section{References}

1. Ang CW, Notermans DW, Hommes M, Simoons-Smit AM, Herremans T (2011) Large differences between test strategies for the detection of anti-Borrelia antibodies are revealed by comparing eight ELISAs and five immunoblots. Eur J Clin Microbiol Infect Dis. doi:10.1007/s10096-011-1157-6 